\title{
Reviews
}

\section{Delay in feed access and spread of hatch: importance of early nutrition}

\author{
H. WILLEMSEN ${ }^{1}$, M. DEBONNE ${ }^{1}$, Q. SWENNEN ${ }^{2}$, N. EVERAERT $^{1}$, \\ C. CAREGHI ${ }^{1}$, H. HAN ${ }^{3}$, V. BRUGGEMAN ${ }^{1}$, K. TONA ${ }^{4}$ and E. DECUYPERE ${ }^{1}$ \\ ${ }^{1}$ Laboratory of Livestock Physiology, Immunology and Genetics, Department of \\ Biosystems, Kasteelpark Arenberg 30, B-3001 Leuven, Belgium; ${ }^{2}$ Centre for \\ Environmental Sciences, Hasselt University, 3590 Diepenbeek, Belgium; \\ ${ }^{3}$ Department of Biochemistry and Molecular Biology, College of Biological Sciences, \\ China Agricultural University; ${ }^{4}$ Department of Animal Production, School of \\ Agriculture University of Lome, Togo \\ *Corresponding author: hilke.willemsen@biw.kuleuven.be
}

In a commercial hatchery, chicks (or poults) hatch over a 24-48 hour period. All chicks remain in the incubator until the majority of the chicks have emerged from the shell. Once removed from the incubator, the newly hatched chick has to undergo several hatchery treatments and is then transported before being placed on the broiler farm. This means that, under practical conditions, chicks are deprived of feed and water for up to 72 hours. In addition, the time of hatch within the hatching window and the spread of hatch cause variability in the amount of time that chicks are feed deprived. Literature on feed deprivation after hatch clearly demonstrates the detrimental effects of any delay in feed access on performance of the chicks with respect to growth, immune system activation, digestive enzyme stimulation and organ development. Improved management strategies, such as shortening the hatching window or the time to first feeding by specific management measures, provide an alternative in dealing with the negative effects caused by a delay in feed access. The development of pre-starter diets that better meet the needs of the newly hatched chicks or in ovo feeding to bridge the gap between hatch and first feeding provide other alternatives in overcoming these problems. However, speculation remains regarding the importance of in ovo or early feeding, or whether the in ovo or early feeding itself is responsible for the beneficial effects reported. The aim of the following review is to discuss the current status of research into early feeding and to stimulate future and further research regarding these topics.

Keywords: feed access; hatching; pre-starter diets; chicks; poults 


\section{Introduction}

Day-old chicks are the end product of the hatchery industry and provide the important starting point for broiler production. The major objective of hatcheries is to obtain a high hatchability of marketable chicks within a narrow spread of hatch. For broiler farmers, these chicks have to perform well, which translates as high viability, growth rate and breast meat yield and low feed conversion. A good-quality one day-old chick is a crucial link between the hatchery and the broiler farm (Decuypere et al., 2001; Decuypere and Bruggeman, 2007).

Chicks do not emerge from their egg all at the same time - there is a hatching window ranging between 24-48 hours (h). In practice, all chicks stay in the incubator until almost all have hatched. This period, added to the time required for hatchery treatments and transport to the broiler farm, means that chicks may be deprived of feed and water for up to 48-72 $\mathrm{h}$. In addition, the spread in hatch causes variability in the delay in time to feed access within one batch of chicks. This delay in feed access has repercussions on the development and growth of the chicks, with the magnitude of the effect of the delay in feed access depending on the hatching time within the hatching window.

This review is intended to give an overview concerning these problems. Firstly, the consequences of delay in feed access early post-hatch will be discussed. Secondly, the importance of the spread of the hatching period will be highlighted along with the consequences of any interaction between delay in feed access and spread of hatch. As one way to overcome negative effects caused by delay in feed access is to provide hatchlings with a pre-starter diet, the final section will discuss the effects of diet composition of pre-starter diets and an overview of already known results given.

\section{Importance of early nutrition}

In practice, both chicks and poults hatch over a period of 24-48 hours and are held in the incubator until a large percentage of the birds have hatched. Hatchery treatments and transport to the farm involve a further holding period of up to 72 hours. During this period, birds normally receive neither food nor water. Despite the contribution of residual yolk to the bird's energy balance, the newly hatched chicks have only a limited ability to assimilate food and water (Nitsan et al., 1991). This results in the mobilisation of body reserves, mainly from subcutaneous fat and liver and potentially from muscles, to support metabolism and maturation of the thermoregulatory system, a process that manifests mainly during the first ten days of the postnatal life (Nichelmann and Tzschentke, 2002).

The importance of early nutrition has already been extensively researched in recent years. The review by Uni and Ferket (2004) gave an overview of the effect of a prolonged holding time after hatch on yolk utilisation, growth and gastro-intestinal development, muscle development and immunological development. However, the effect of delay in feed access and hormones and metabolites as well as on development of homeothermy has not been described in detail in literature yet. Results obtained in our laboratory have given an initial insight in the effect of early nutrition on hormone and metabolite levels and the development of homeothermy.

\section{HORMONES AND METABOLITES}

Careghi et al. (2005) showed that chicks suffering from delay in feeding time have lower plasma $\mathrm{T}_{3}$ levels, suggesting an overall lower metabolic rate, which agrees with the results of Noy and Sklan (2001). Unpublished results obtained in our laboratory showed differential effects between fed and feed-delayed chicks on protein and lipid metabolism. 
Decreased levels of plasma uric acid and triglycerides after $36-48 \mathrm{~h}$ of starvation suggest a decrease in amino acid oxidation and hepatic lipogenesis, respectively. However, plasma levels of glucose, as a measure for carbohydrate metabolism, were not affected by feed deprivation. In addition, initial feeding of starved chicks resulted in heightened levels of plasma uric acid, triglycerides and glucose concentration, which dropped to normal levels thereafter, probably due to feedback mechanisms as described for 3 to 6 week old broiler chickens by Swennen et al. (2005).

\section{DEVELOPMENT OF HOMEOTHERMY}

Decuypere and Kühn (1988) found that chicks fasted for $16 \mathrm{~h}$ before a short-term cold exposure had a greater decrease in body temperature than their fed counterparts, and this was maintained throughout the first week of life. In combination, they also found that these conditions resulted in a decreased serum $\mathrm{T}_{3}$ level and an increased serum $\mathrm{T}_{4}$ level, which was the reverse to that observed for chicks that were fed before cold exposure. This effect of feed restriction on the thyroid hormone levels was substantiated by King et al. (1977), May (1978), Harvey and Klandorf (1983), Klandorf and Harvey (1985), Scanes and Griminger (1990), Kühn et al. (1991), Darras et al. (1995, 1998) and Van der Geyten et al. (1999). According to the study of Van der Geyten et al. (1999), hepatic $\mathrm{D}_{3}$, an iodothyronine deiodinase that inactivates $\mathrm{T}_{3}$ or $\mathrm{T}_{4}$ by inner ring deiodination (St. Germain and Galton, 1997) appears to play a central role in the regulation of plasma $T_{3}$ during fasting and re-feeding in the chicken. All these observations in combination with the knowledge that thyroid hormones have a crucial role in the thermoregulatory system (Debonne et al., 2008) leads to the hypothesis that a delay in feed access from the moment of hatch onwards impairs the thermoregulatory abilities of newly hatched chicks. This implies that if no feed can be provided after hatch for whatever reason, climatic conditions have to be adapted towards a higher environmental temperature to preserve the quality of the chick when placed on the farm.

\section{Importance of time of hatch within a hatching window and spread of hatch between different hatching windows}

Much research has already been conducted to elucidate the effects of early feeding. However, most investigators did not take into account the differences in biological age due to spread of hatch.

\section{CHRONOLOGICAL AND BIOLOGICAL AGE}

In general, the delay in time before chicks are fed for the first time is calculated by the time spent in the hatchery after hatch (for treatments such as sexing and vaccination), added to the transportation time to the broiler farm. In addition, the added 'hatch window' of 24 to $48 \mathrm{~h}$ (early versus late hatchers) must be taken into consideration (Decuypere et al., 2001) (Figure 1). Due to this spread in hatch, chicks not only differ in biological age, but also in quality (Bamelis et al., 2005; Tona et al., 2003; Willemsen et al., 2008). 


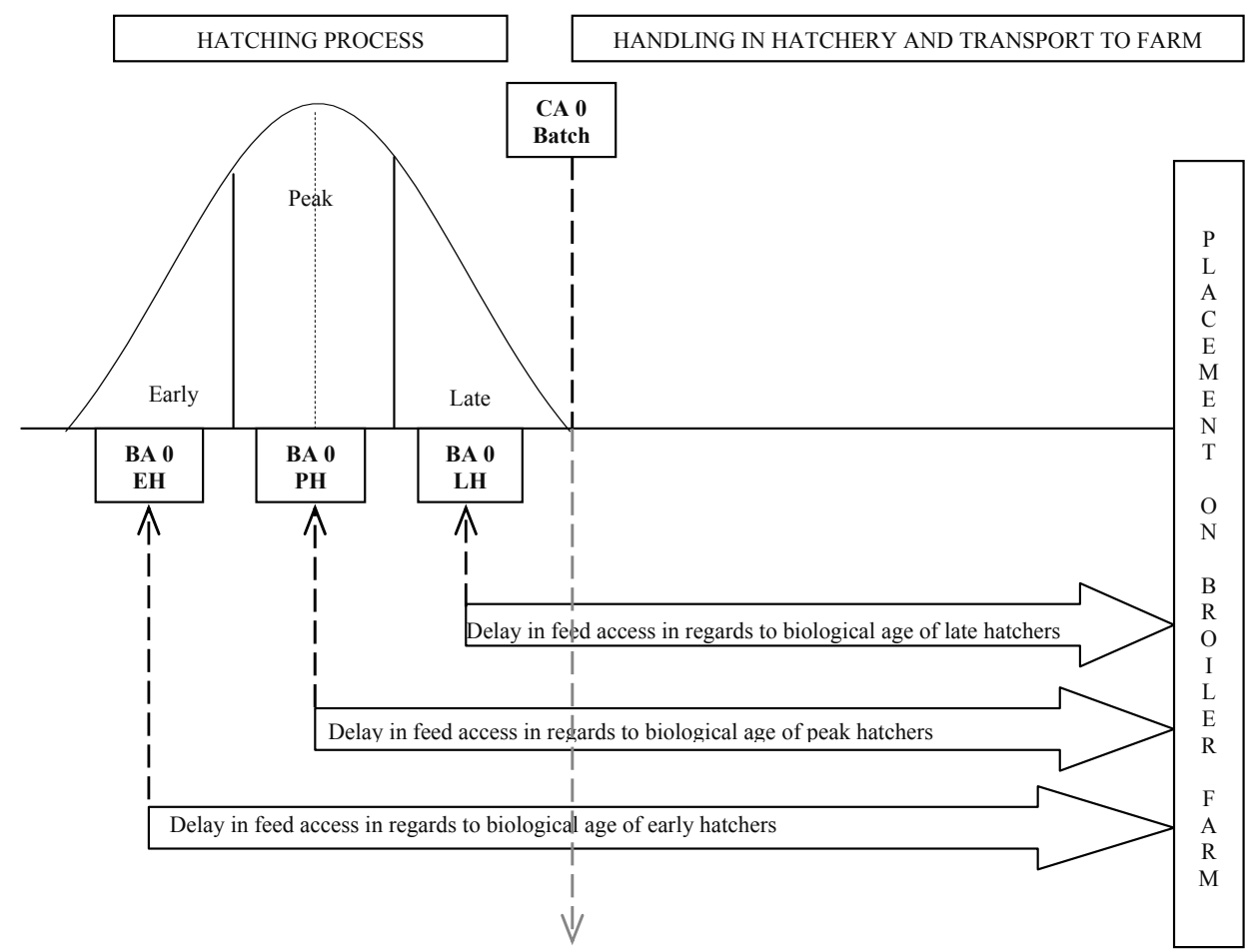

Figure 1 Schematic overview of the difference between biological and chronological age as the interaction with time of hatch within a hatching window is highlighted. Biological age is defined as the age in days in reference to the exact time of hatch while chronological age is defined as the age in days in reference to the end of hatch of the whole batch. Late hatchers have a smaller delay in feed access than peak hatchers which in turn have a smaller delay in feed access than early hatchers.

BA: Biological age; CA: Chronological age; EH: Early hatchers; PH: Peak hatchers; LH: Late hatchers.

A study by Careghi et al. (2005) underlined the importance of the difference between biological and chronological age of chicks. Biological age (BA) of chicks is defined as the age in days in reference to the exact time of hatch while chronological age (CA) is defined as the age in days in reference to the end of hatch of the whole batch. The relative growth $(\mathrm{RG})$ of chicks from hatch to BA $2 \mathrm{~d}$ is twice as low for early hatchers as for late hatchers and stays higher for these late hatchers until BA $7 \mathrm{~d}$ when kept under conditions of immediate access to food. In contrast, no difference was found between late and early hatchers in RG at chronological age $7 \mathrm{~d}$ when feed was provided immediately (Careghi et al., 2005). The egg weight at the start of incubation seems to have an effect on the time of hatch within the hatch window, as Careghi et al. (2005) found that early hatchers had a significantly lower starting egg weight as compared to late hatchers. In addition, a corresponding trend in higher hatching weight for the late hatchers was reported. An even more important observation made by these authors was the significant interaction between BA of chicks and delay in feeding time. At BA 4 d, the fasted chicks still had greater RG than the chicks that had been reared with feed. In addition, delayed feeding had a profoundly depressing effect on the growth to $7 \mathrm{~d}$ of late hatchers when CA was taken into account, a condition that was not apparent when BA was considered. An explanation in the differential growth rate to $7 \mathrm{~d}$ of age may be partly due to the 
differences in the levels of intestinal development and utilization of nutrients as described above. Other unknown intrinsic factors related to time of hatch may be involved in posthatch growth potential of differently hatched groups.

\section{SPREAD OF HATCH}

Delay in feed does not have the same effect on early and late hatchers, as late hatchers benefit more from early access to feed after hatch than early hatchers both when taken at biological or chronological similar ages after hatch (Careghi et al., 2005). Therefore, it can be stated that the time of hatch within a hatching window is an important factor that aggravates the negative effect of delay in feed access (Careghi et al., 2005). Moreover, the magnitude of the effect of delayed feeding is not only dependent on the hatching period within the hatching window, but also on the spread of hatch between batches (Decuypere and Bruggeman, 2007) as demonstrated in Figure 2. The difference in the effect of delay in feed access between early and late hatchers, in practice conditions, becomes very obvious when the spread of hatch is smaller / larger. The duration of feed deprivation of late hatchers is little influenced by the spread of hatch, while in peak hatchers and early hatchers this severely decreases when the spread of hatch is smaller. In addition, the spread of the hatch is affected by incubation conditions as temperature, turning conditions or gaseous environment as well as by pre-incubation conditions as egg storage duration and the age of parent stock (Decuypere and Bruggeman, 2007).

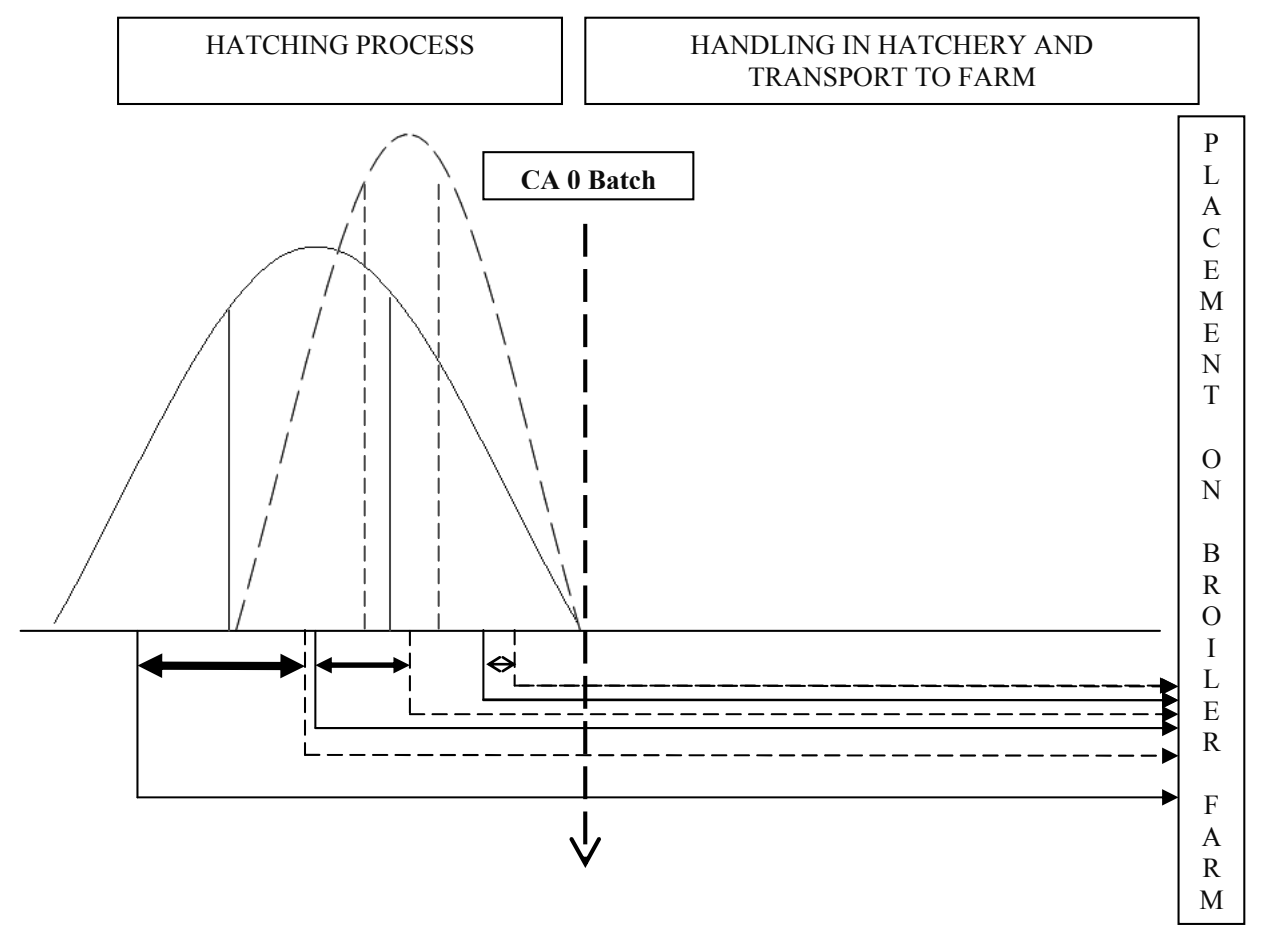

Figure 2 Effect of spread of hatch on the interaction between delay in feed access and time of hatch within the hatching window. The difference in duration of feed deprivation of late $(\leftrightarrow)$, peak $(\longleftrightarrow) \longleftrightarrow)$ and early $(\longleftrightarrow)$ hatchers between batches with a small $(--)^{-}$) or large $(\longrightarrow)$ spread of hatch is shown. The duration of delay in feed access is very little influenced for late hatchers, while in peak and early hatchers it severely increases when spread of hatch is larger. CA: chronological age. 


\section{GLUCOSE, THYROID HORMONES AND HEAT PRODUCTION}

The spread of hatching time seems to affect the ability of newly-hatched chicks to use ingested glucose (unpublished results). Newly-hatched chicks have to make a transition from an endogenous lipid-rich yolk to carbohydrate-rich exogenous feed. As yolk lipids are depleted a few days after hatch, after which glucose becomes the primary energy source (Sklan, 2003), chicks need to obtain a high capacity for degrading and ingesting carbohydrates soon after hatch. Late hatchers, when fed immediately after hatch, use glucose faster or possibly more efficiently than the early and peak hatchers (unpublished results). In combination with such digestive enzyme maturation (Moran, 1985), it provides them with the ability to use exogenous carbohydrates sooner than early hatchers. In addition, heat production, as a measurement for metabolic rate, was dependent on time of hatch. Heat production increases with age, although this increase appeared to be smaller for early hatchers (unpublished results). The combination of these two observations leads to the conclusion that the hatching time has an influence on the metabolic rate of the chicks during the first week of life. However, in a previous experiment (Careghi et al., 2005) no differences in plasma $T_{3}$ levels were found between early and late hatchers when feed was provided immediately after hatch. In contrast, when chicks were delayed in feed access, a clear effect on plasma $\mathrm{T}_{3}$ levels was observed. Chicks with a $48 \mathrm{~h}$ delay in feed access showed lower plasma $\mathrm{T}_{3}$ levels compared with chicks which had immediate access to feed. In addition, late hatchers exhibited lower plasma $\mathrm{T}_{3}$ levels during the fasting period than early hatchers. When chicks were fed, $\mathrm{T}_{3}$ levels increased significantly to normal basal values. Noy and Sklan (2001) reported the same observation.

\section{NEW TECHNOLOGIES}

Because of the literature cited above, there is great interest in ways to aid chick nutrition before placement, as Careghi et al. (2005) suggested, by providing an energy source in the hatching basket and during transport. New technologies to overcome these problems are available. Some hatchery management experts have come up with an alternative housing system where these problems are addressed. In 2006, a new concept of early housing system in which pre-hatched eggs are brought in at day 18 of incubation in order to hatch under the novel regime, was introduced. When chicks emerge from their eggs they fall on a litter belt where food and water is immediately available and where they can stay from 7 to $10 \mathrm{~d}$ post-hatch before being transferred to the traditional broiler farm. This housing system serves both as a hatchery and a broiler housing system. According to Horrox (2006), this type of housing system should result in chicks and poults equivalently one day ahead in development compared to standard industry practice. However, it requires heavy investment in new equipment and changes in logistics by hatcheries (de Oliveira, 2007).

Another possible solution is to provide hatchling supplements at the hatchery and/or at placement at the farm. Products such as Oasis (Novus International), Galito (Vitamex) and Gro-Gel (Dawe's Laboratories) are being used to promote early growth and liveability of poultry. The Oasis hatching supplement is a semi-solid hydrated nutritional supplement that contains $70 \%$ water, $10 \%$ protein, $20 \%$ carbohydrate and less than $1 \%$ fat (Batal and Parson, 2002). Benefits of post-hatch feeding supplement have been reported by Noy and Sklan (1999b) and Batal and Parsons (2002). Although their results indicated that feeding Oasis (compared to fasting) had beneficial effects on growth performance, no significant differences were found between different forms of early nutrition (traditional solid feed, semi-solid feed (Oasis) or liquid nutrients). The beneficial effects of hatching supplements are explained by the fact that these chicks had immediate access to feed, whatever the form of the early nutrition. This leads to the 
hypothesis that it may not be the kind of feed itself, but more the stimulatory effect of whatever feed on GIT secretions, growth factors or neuronal factors that initiates the further development of the GIT and therefore gives advantage to chicks given early feed access.

\section{Macronutrient composition of the pre-starter diet}

The first week after hatch is an extremely important time for all young poultry. During the past 40 years, the market age of broiler chickens has been reduced by approximately one day each year. Nowadays, the first $7 \mathrm{~d}$ represent approximately $17 \%$ of the growing period in time and $5-10 \%$ in weight as a percentage of final body weight (Lilburn, 1998; Havenstein et al., 2003). Moreover, the body weight at $7 \mathrm{~d}$ of age appears to be a good predictor for the body weight at slaughter age, with correlations ranging from 0.4 to 0.5 , depending on breeder line and parent stock age (Willemsen et al., 2008).

\section{THE NEED FOR A PRE-STARTER DIET}

Today's broiler feeding programs provide a starter feed from chick placement to $10 \mathrm{~d}$ of age. However, the chicks' requirements change quickly during their first weeks of life, and this should be taken into account when composing starter diets (Swennen et al., 2009). After hatch, a major change occurs in the source of available nutrients for the neonatal chick; switching from endogenous lipid-rich yolk to exogenous carbohydrate and protein rich feed (Noy and Sklan, 1999a). As already mentioned, the digestive tract has to undergo major morphological and physiological changes in the first week after hatch, to allow proper digestion and utilisation of ingested nutrients. The uptake of solid feed promotes these necessary changes in the morphology of the digestive tract and its secretions. It has already been proven, as described above, that a delay in first feeding, as occurs in practice, leads to a reduced performance of the chicks with respect to growth, immune system activation, digestive enzyme stimulation and organ development (Pinchasov and Noy, 1993; Noy and Sklan, 1999a; Dibner, 1999; Gonzales et al., 2003; Bigot et al., 2003). The first days post-hatch are therefore very critical to the development and survival of commercial chicks and poults. The first priority of an early nutrition program should thus be to better meet the specific needs of the newly hatched chicks with a pre-starter diet (Lilburn, 1998). In addition, optimal nutrition in the first week should take into account the contribution of the yolk and the ability of the immature gut to effectively utilize exogenous feed (Swennen et al., 2009).

The ratio between macronutrients has a major influence on post-hatch performance and body composition of broiler chickens (Buyse et al., 1992; Nieto et al., 1997; Smith and Pesti, 1998; Bregendahl et al., 2002; Collin et al., 2003; Swennen et al., 2007). Several studies in broilers have been performed with diets in which the iso-energetic substitution of one particular macronutrient was done only by one other macronutrient while keeping the third macronutrient at a constant level. For a review on this topic see Swennen et al. (2007).

\section{MACRONUTRIENT COMPOSITION OF THE PRE-STARTER DIET}

In unpublished results obtained in our laboratory, it was shown that the macronutrient composition of the diet has a clear effect on the switch that newly hatched chicks make from utilisation of lipid rich yolk to the carbohydrates in the diet. Using the glucose oxidation breath test, it was shown that chicks fed a low protein diet appear to use more of the carbohydrates present in the formulation than chicks fed a diet with a low fat content, although the level energy was similar in both diets. It was clear that chicks fed 
the diet with lower protein level had a significantly higher heat production and respiratory coefficient during the first three days post-hatch. This observation was further supported by the higher levels of $\mathrm{T}_{3}$ present in the plasma. These observations lead to the conclusion that chicks fed a low protein diet have an excess intake of energy compared with intake of protein (unpublished results). Swennen et al. (2009) investigated the influence of iso-energetic substitutions between the three macronutrients in pre-starter diets on performance and intermediary nutrient metabolism in broiler chickens. When fed a low protein pre-starter from hatch until d 5 post-hatch, chicks had a significantly lower body weight until d 28, compared to chicks fed an iso-energetic low carbohydrate or low fat pre-starter. At slaughter age this difference in body weight was still visible, although not statistically different. However, no influence of dietary composition of the pre-starter diet on feed intake was found. In contrast, Noy and Sklan (2002) reported an increased feed intake with a decreasing crude protein (CP) level but did not find an effect of pre-starter protein level on growth. These seemingly contradictory results are most likely explained by the fact that the dietary compositions in both studies are not comparable. Perhaps the increased feed intake compensated in the experiments of Noy and Sklan (2002) for the depressing effects of low CP on growth. In addition, Swennen et al. (2009) found that plasma metabolite levels, like triglycerides, uric acid, glucose and free fatty acids, are influenced mostly by the low protein pre-starter diet. In another study performed by Everaert et al. (2010), the relative growth of chicks receiving a high protein diet during the first $5 \mathrm{~d}$ post-hatch was enhanced after the pre-starter diet treatment (from d 5 until d 7). While no differences in relative breast muscle weight were found, S6K1 and rpS6 (ribosomal protein $\mathrm{S} 6$ or the downstream target of S6K1) were activated by high protein levels in neonatal chicks, which lead to the conclusion that increasing protein above animal requirement enhanced the activation of components related to translation initiation in neonate chick muscle (Everaert et al., 2010).

\section{IMPORTANCE OF PROTEIN LEVEL OF PRE-STARTER DIET}

Research on early nutrition indicated that proteins are the most important macronutrient present in the pre-starter diet. As Noy and Sklan (2002) concluded, once limiting amino acids and energy are provided at a sufficient level, the influence of dietary composition on immediate post-hatch growth becomes limited. However, as seen in the study by Swennen et al. (2009), caution is necessary as it cannot be guaranteed that low protein diets deliver the necessary amount of nitrogen for the synthesis of non-essential amino acids, leading to a reduced protein synthesis (Sklan and Plavnik, 2002). These results are similar to those obtained in older broiler chickens, where dietary protein content also had a larger impact on growth, energy and protein metabolism and on intermediary metabolites compared to the carbohydrate and fat fraction in iso-energetically formulated diets (reviewed by Swennen et al., 2007).

\section{IMPORTANCE OF THE RESIDUAL YOLK}

The importance of the residual yolk, already highlighted by Murakami et al. (1992), was emphasised in the study of Swennen et al. (2009) as the residual yolk appeared to be of high importance when chicks were fed diets with different macronutrient content. Chicks fed the low protein diet showed the highest utilisation of the yolk during the first two days, in spite of the fact that the low protein, low fat and low carbohydrate diets were iso-energetic. This observation confirms that of Wertelecki and Jamroz (2005) i.e. a reduced protein level in the pre-starter diet stimulates the rate of re-absorption of the yolk sac contents. The increased re-absorption of the residual yolk in the low protein fed chicks suggests that the protein restriction in the pre-starter diet is more severe than the 
restriction in lipids or carbohydrates or that newly hatched chicks might be more sensitive to a shortage in protein than in lipids or carbohydrates. This may partly be explained by the fact that the efficiency of protein digestion is lower than that of lipids and carbohydrates in the first days after hatch (Noy and Sklan, 1999c).

\section{Interaction of early feeding and in ovo feeding}

The pre-natal/perinatal period is a critical period in the development of the chick embryo because of its high caloric demand to fuel the hatching process and basal metabolism (Ferket and Uni, 2006). Maintaining sufficient glycogen reserves is of vital importance for surviving the demanding hatching process and for making the transition from endogenous to exogenous nutrition. As described earlier, delaying early feeding due to common hatchery practises will constrain the genetic potential for the future performance of broilers. These adverse effects can be neutralised or abolished by providing feed straight after the chick has hatched. However, under practical circumstances in the hatchery management, this is difficult to realise but alternatives are available such as a special housing system and supplementation with specialist feedstuffs. In ovo feeding (IOF), i.e. the injection of nutrients in the egg before or during incubation, forms another promising alternative. Many studies have been conducted concerning the development of techniques for in ovo feeding which have been patented (Uni and Ferket, US patent, 6.592.878). These researchers concluded that in ovo feeding must be applied while the embryo consumes the amniotic fluid, being around embryonic day (ED) 17 until ED 18 for chicken embryos, as the amniotic fluid is orally consumed by the embryos towards hatch and therefore nutrients are delivered to the embryonic intestine. It appears that both IOF and early feeding appeal to the same mechanisms in improving later performance. Stimulation of GIT development in ovo is initiated with intestinal presentation of amniotic contents while feed intake after hatching will cause a further stimulation. In addition, both IOF and early feeding after hatch improve body weight until at least 35 days post-hatch (Uni and Ferket, 2004; Uni et al., 2005). Therefore, the question arises if there is a carry-over effect of IOF on the already beneficial effects of early feeding after hatch. An argument for this carry-over effect is based on muscle growth post-hatch. Satellite cell mitotic activity is the highest in the perinatal period and decreases with birds age (Velleman, 2007). As mentioned earlier, delay in feed access decreases satellite cell mitotic activity when compared to their fed counterparts (Halevy et al., 2000; Mozdziak et al., 2002; Moore et al., 2005). Therefore, in ovo feeding may induce proliferation of myoblasts during embryonic development and could be responsible for a higher number of satellite cells in early post-hatch development.

\section{Conclusions}

In commonly-used poultry practice, hatched chicks have a delayed feed access for up to $72 \mathrm{~h}$, due to the spread in hatching time in combination with other treatments, manipulations and transport to the broiler farm. It has already been extensively documented that such early feed deprivation has detrimental effects on the development and later performance of the chick. In addition, both the time of hatch within a hatching window and the spread of hatch are two important factors that can exacerbate the negative effect of delay in feed access. Several factors or techniques may help to alleviate these problems: 
(1) In ovo feeding with adapted composition of nutrients to bridge the gap between hatch and first feeding

(2) Shortening the hatching window by specific conditions in the hatchery and/or even in the setter machine

(3) Shortening the time of first feeding by specific management measures e.g. new technologies for hatching as well as for early feeding, like oasis supplements

(4) Early nutrition programs or specific pre-starters as well as climatic conditions that better meet the needs of food deprived hatchlings

It remains a matter of debate whether in ovo or early feeding by itself is responsible and sufficient or if a specific composition of in ovo or early feed provided is necessary and the most important factor for the observed beneficial effects as mentioned in literature. Therefore, with this review the authors would like to stimulate future and further research regarding these topics.

\section{References}

BAMELIS, F., KEMPS, B., MERTENS, K., DE KETELAERE, B., DECUYPERE, E. and DE BAERDEMAEKER, J. (2005) An automatic monitoring of the hatching process based on the noise of the hatching chicks. Poultry Science 84: 1101-1107.

BATAL, A. and PARSONS, C. (2002) Effect of fasting versus feeding oasis after hatching on nutrient utilization in chicks. Poultry Science 81: 853-859.

BIGOT, K., MIGNON-GRASTEAU, S., PICARD, M. and TESSERAUD, S. (2003a) Effects of delayed feed intake on body, intestine, and muscle development in neonate broilers. Poultry Science 82: 781-788.

BREGENDAHL, K., SELL, J.L. and ZIMMERMAN, D.R. (2002) Effect of low-protein diets on growth performance and body composition of broiler chicks. Poultry Science 81: 1156-1167.

BUYSE, J., DECUYPERE, E., BERGHMAN, L., KÜHN, E.R. and VANDESANDE, F. (1992) Effect of dietary protein content on episodic growth hormone secretion and on heat production of male broiler chickens. British Poultry Science 33: 1101-1109.

CAREGHI, C., TONA, K., ONAGBESAN, O., BUYSE, J., DECUYPERE, E. and BRUGGEMAN, V. (2005) The effects of the spread of hatch and interaction with delayed feed access after hatch on broiler performance until seven days of age. Poultry Science 84: 1314-1320.

COLlin, A., MALHEIROS, R.D., MORAES, V.M.B., VAN AS, P., DARRAS, V.M., TAOUIS, M., DECUYPERE, E. and BUYSE, J. (2003) Effects of dietary macronutrient content on energy metabolism and uncoupling protein mRNA expression in broiler chickens. British Journal of Nutrition 90: 261-269.

DARRAS, V.M., COKELAERE, M., DEWIL, E., ARNOUTS, S., DECUYPERE, E. and KÜHN, E.R. (1995) Partial food restriction increases hepatic inner ring deiodinating activity in the chicken and the rat. General Comparative Endocrinology 100: 334-338.

DARRAS, V.M., MOL, K.A., VAN DER GEYTEN, S. and KÜHN, E.R. (1998) Control of peripheral thyroid hormone levels by activating and inactivating deiodinases. Trends in Comparative Endocrinology and Neurobiology 839: 80-86.

DE OLIVEIRA, J. (2007) Effects of In ovo Feeding on Turkey Embryos Development, Energy Status, Intestinal Maturation, Gene Expression and Post-hatch Development. Ph. D. Thesis, North Carolina State University.

DEBONNE, M., BAARENDSE, P.J.J., VAN DEN BRAND, H., KEMP, B., BRUGGEMAN, V. and DECUYPERE, E. (2008) Involvement of the hypothalamis-pituitary-thyroid axis and its interaction with the hypothalamic-pituitary-adrenal axis in the ontogeny of avian thermoregulation: a review. World's Poultry Science Journal 64: 309-321.

DECUYPERE, E. and BRUGGEMAN, V. (2007) The endocrine interface of environmental and egg factors affecting chick quality. Poultry Science 86: 1037-1042.

DECUYPERE, E. and KÜHN, E.R. (1988) Alterations in thyroid hormone physiology induced by temperature and feeding in newly hatched chickens. Acta physiologica Polonica 39: 380-394.

DECUYPERE, E., TONA, K., BRUGGEMAN, V. and BAMELIS, F. (2001) The day-old chick, a crucial hinge between breeders and broilers. World's Poultry Science Journal 57: 127-138.

DIBNER, J. (1999) Avoid any delay. Feed International December: 30-34. 
EVERAERT, N., SWENNEN, Q., METAYER-COUSTARD, S., WILLEMSEN, H., CAREGHI, C., BUYSE, J., BRUGGEMAN, V., DECUYPERE, E. and TESSERAUD, S. (2010) The effect of the protein level in a pre-starter diet on the post-hatch performance and activation of S6K1 in muscle of neonatal broilers. British Journal of Nutrition 103: 206-211.

FERKET, P. and UNI, Z. (2006) Early feeding - in ovo feeding enhances of early gut development and digestive capacity of poultry. XII European Poultry Conference, Verona, Italy, 10-14 September 2006.

GONZALES, E., KONDO, N., SALDANHA, E., LODDY, E., CAREGHI, C. and DECUYPERE, E. (2003) Performance and physiological parameters of broiler chickens subjected to fasting on the neonatal period. Poultry Science 82: 1250-1256.

HALEVY, O., GEYRA, A., BARAK, M., UNI, Z. and SKLAN, D. (2000) Early post-hatch starvation decreases satellite cell proliferation and skeletal muscle growth in chicks. Journal of Nutrition 130: 858-864.

HARVEY, S. and KLANDORF, H. (1983) Reduced adrenocortical function and increased thyroid function in fasted and refed chickens. Journal of Endocrinology 98: 129-135.

HAVENSTEIN, G.B., FERKET, P.R. and QURESHI, M.A. (2003) Growth, livability and feed conversion of 1957 versus 2001 broilers when fed representative 1957 and 2001 broiler diets. Poultry Science 82: 15001508.

HORROX, N. (2006) World focus: a good start, time for a rethink? International Poultry Production 14: 5.

KING, D.B., KING, C.R. and ESHLEMAN, J.R. (1977) Serum triiodothyronine levels in the embryonic and post-hatching chicken, with particular reference to feeding-induced changes. General Comparative Endocrinology 31: 216-223.

KLANDORF, H. and HARVEY, S. (1985) Food intake regulation of circulating thyroid hormones in domestic fowl. General Comparative Endocrinology 60: 162-170.

KÜHN, E.R., HERREMANS, M., DEWIL, E., VANDERPOOTEN, A., RUDAS, P., BARTHA, T., VERHEYEN, G., BERGHMAN, L. and DECUYPERE, E. (1991) Thyrotropin-releasing hormone (TRH) is not thyrotropic but somatotropic in fed and starved adult chickens. Reproduction, nutrition and development 31: 431-439.

LILBURN, M.S. (1998) Practical aspects of early nutrition for poultry. Journal of Applied Poultry Research 7: 420-424.

MAY, J.D. (1978) Effect of fasting on $\mathrm{T}_{3}$ and $\mathrm{T}_{4}$ concentrations in chicken serum. General Comparative Endocrinology 34: 323-327.

MOORE, D., FERKET, P. and MOZDZIAK, P. (2005) Early post-hatch fasting induces satellite cell selfrenewal. Comparative Biochemistry and Physiology Part A 142: 331-339.

MORAN, E.T. Jr. (1985) Digestion and absorption of carbohydrates in fowl and events through perinatal development. Journal of Nutrition 115: 665-674.

MOZDZIAK, P., WALSH, T. and McCOY, D. (2002b) The effect of early post-hatch nutrition on satellite cell mitotic activity. Poultry Science 81: 1703-1708.

MURAKAMI, H., AKIBA, Y. and HORIGUCHI, M. (1992) Growth and utilization of nutrients in newlyhatched chick with or without removal of residual yolk. Growth, Development and Aging 56: 75-84.

NICHELMANN, M. and TZSCHENTKE, B. (2002) Ontogeny of thermoregulation in precocial birds. Comparative Biochemistry and Physiology Part A 131: 751-763.

NIETO, R., AGUILERA, J.F., FERNANDEZ-FIGARES, I. and PRIETO, C. (1997) Effect of a low protein diet on the energy metabolism of growing chickens. Archiv für Tierernahrüng 50: 105-119.

NITSAN, Z., BEN-AVRAHAM, G., ZOREF, Z. and NIR, I. (1991) Growth and development of the digestive organs and some enzymes in broiler chicks after hatching. British Poultry Science 32: 515-523.

NOY, Y. and SKLAN, D. (1999a) The importance of early nutrition for chicks. Proceedings of the $12^{\text {th }}$ symposium on Poultry Nutrition, the Netherlands, pp.143-151.

NOY, Y. and SKLAN, D. (1999b) The effect of different types of early feeding on performance in chicks and poults. Journal of Applied Poultry Research 8: 16-24.

NOY, Y. and SKLAN, D. (1999c) Energy utilization in the newly hatched chicks. Poultry Science 78: 17501756.

NOY, Y. and SKLAN, D. (2001) Yolk and exogenous feed utilization in the post-hatch chick. Poultry Science 80:1490-1495.

NOY, Y. and SKLAN, D. (2002) Nutrient use in chicks during the first week post-hatch. Poultry Science 81: 391-399.

PINCHASOV, Y. and NOY, Y. (1993) Comparison of post-hatch holding time and subsequent early performance of broiler chicks and turkey poults. British Poultry Science 34: 111-120.

SCANES, C.G. and GRIMINGER, P. (1990) Endocrine-nutrition interactions in birds. Journal of Experimental Zoology Supplement 4: 98-105.

SKLAN, D. (2003) Fat and carbohydrate use in posthatch chicks. Poultry Science 82: 117-122.

SKLAN, D. and PLAVNIK, I. (2002) Interactions between dietary crude protein and essential amino acid intake on performance in broilers. British Poultry Science 43: 442-449. 
SMITH, E.R. and PESTI, G.M. (1998) Influence of broiler strain cross and dietary protein on the performance of broilers. Poultry Science 77: 276-281.

ST. GERMAIN, D.L. and GALTON, V.A. (1997) The deiodinase family of selenoproteins. Thyroid 7: 655668.

SWENNEN, Q., DECUYPERE, E. and BUYSE, J. (2007) Implications of dietary macronutrients for growth and metabolism in broiler chickens. Worlds Poultry Science Journal 63: 541-556.

SWENNEN, Q., EVERAERT, N., DEBONNE, M., VERBAEYS, I., CAREGHI, C., TONA, K., JANSSENS, G.P.J., DECUYPERE, E., BRUGGEMAN, V. and BUYSE， J. (2009) Effect of macronutrient ratio of the pre-starter diet on broiler performance and intermediary metabolism. Journal of animal physiology and animal nutrition, epub ahead of print (PMID 19747420).

SWENNEN, Q., JANSSENS, G.P., MILLET, S., VANSANT, G., DECUYPERE, E. and BUYSE, J. (2005) Effects of substitution between fat and protein on feed intake and its regulatory mechanisms in broiler chickens: endocrine functioning and intermediary metabolism. Poultry Science 84: 1051-1057.

TONA, K., BAMELIS, F., DE KETELAERE, B., BRUGGEMAN, V., MORAES, V.B.M., BUYSE, J., ONAGBESAN, O. and DECUYPERE, E. (2003) Effects of egg storage time on spread of hatch, chick quality and chick juvenile growth. Poultry Science 82: 736-741.

UNI, Z. and FERKET, R.P. (2004) Methods for early nutrition and their potential. World's Poultry Science Journal 60: 101-111.

UNI, Z., FERKET, P.R., TAKO, E. and KEDAR, O. (2005) In ovo feeding improves energy status of lateterm chicken embryos. Poultry Science 84: 764-770.

VAN DER GEYTEN, S., VAN ROMPAEY, E., SANDERS, J.P., VISSER, T.J., KÜHN, E.R. and DARRAS, V.M. (1999) Regulation of thyroid hormone metabolism during fasting and refeeding in chicken. General and Comparative Endocrinology 116: 272-280.

VELLEMAN, S.G. (2007) Muscle development in the embryo and hatchling. Poultry Science 86: 1050-1054.

WERTELECKI, T. and JAMROZ, D. (2005) The effect of protein level in early feeding on yolk sac nutrient concentrations in chickens. Journal of Animal Feed Science 14: 503-506.

WILLEMSEN, H., EVERAERT, N., WITTERS, A., DE SMIT, L., DEBONNE, M., VERSCHUERE, F., GARAIN, P., BERCKMANS, D., DECUYPERE, E. and BRUGGEMAN, V. (2008) Critical assessment of chick quality measurements as an indicator of post-hatch performance. Poultry Science 87: 2358-2366. 